\title{
THE IMPACTS OF INTELLECTUAL CAPITAL ON FINANCIAL PERFORMANCE: AN EVIDENCE FROM INDONESIAN MANUFACTURING INDUSTRY
}

\author{
Josua Tarigan*), Stephanie Listijabudhi*), S. Elsye Hatane*), and D. Christine Widjaja*) \\ *) Faculty of Economics, Petra Christian University \\ Jl. Siwalankerto 121-131, Surabaya, Indonesia
}

\begin{abstract}
The purpose of the research was to provide an examination of the impacts of the intellectual capital on the firms' financial performance that is focusing on profitability, productivity, and market value. It was conducted on manufacturing companies in Indonesia which were listed in Indonesian Stock Exchange (IDX). The samples of this research were 93 listed manufacturing companies with the total number of 465 firm-year observations in five years. VAIC method by Pulic was used in measuring the intellectual capital in this research. Based on VAIC approach, intellectual capital consisted of human capital (HCE), structural capital (SCE), and capital employed (CEE). There were ten regression models used to assess all the relationships of independent and dependent variables. The result showed that VAIC had significant relationship towards financial performance but not towards the market value of the companies. While in regards to each component, $\mathrm{HCE}$ was found to have no correlation towards both market value and financial performance. The SCE was found to have a negative significant relationship only towards the market value. Meanwhile, CEE was proved to have a significant relationship towards both market value and financial performance.
\end{abstract}

Keywords: intellectual capital, financial performance, market value, VAIC, manufacturing industry

\begin{abstract}
Abstrak: Penelitian ini bertujuan menguji dampak yang dimiliki oleh Intellectual Capital terhadap kinerja keuangan perusahaan, yang fokus pada profitabilitas, produktivitas, dan nilai pasar perusahaan. Studi ini dilakukan pada perusahaan manufaktur Indonesia yang terdaftar dalam Bursa Efek Indonesia. Penelitian ini dilakukan pada 93 perusahaan terbuka selama lima tahun dengan total obeservasi 465 tahun laporan. Metode VAIC yang dipopulerkan oleh Pulic digunakan untuk mengukur Intellectual Capital. Berdasarkan Metode VAIC, Intellectual Capital terdiri dari tiga komponen yaitu Human Capital (HCE), Structural Capital (SCE), dan Capital Employed (CEE). Terdapat sepuluh persamaan regresi yang digunakan untuk menganalisa hubungan antara variabel bebas dan terikat. Hasil penelitian yang didapatkan menunjukkan VAIC memiliki hubungan yang signifikan terhadap kinerja keuangan perusahaan, namun tidak untuk nilai pasar perusahaan. Sedangkan tidak ditemukan hubungan yang signifikan antara HCE dengan nilai pasar dan kinerja keuangan perusahaan. Untuk SCE memiliki hubungan negatif yang signifikan dengan nilai pasar perusahaan, sedangkan untuk CEE ditemukan memiliki hubungan yang signifikan dengan nilai pasar dan kinerja keuangan perusahaan.
\end{abstract}

Kata kunci: intellectual capital, kinerja keuangan, harga pasar perusahaan, VAIC, industri manufaktur

${ }^{1}$ Corresponding author:

Email: josuat@petra.ac.id 


\section{INTRODUCTION}

In today economy, intellectual capital has become a crucial resource for an organization. To cope with rapid changes and high competition in the market, an organization should continuously make an investment in updating the knowledge and development of the skills of its employees so it can be successful in the long term. Besides, the economy is also slowly shifting towards the knowledge-based economy and resourcebased economy, where more dependency and attention on information technology, skill, and knowledge from employees are put rather than the tangible asset. This has encouraged many companies to be concerned about their intellectual capital (Muhammad and Ismail, 2009). Companies are encouraged to put more effort and attention on their employees' quality to be able to respond to market transformation. Intellectual capital includes knowledge and skills from all levels of organization, and it has become a new important resource in today new economy replacing physical and financial capitals.

Once companies understand the concept of intellectual capital, it is more likely for them to be successful since they understand that intellectual capital is very valuable. Thus continual update on their knowledge and abilities will be done to compete with others (Huffman, 2012). In other words, intellectual capital if managed and invested well could be transformed into a competitive advantage for the companies. It can't be neglected that the increased crucial role and importance of intellectual capital in economy nowadays is also affected due to the ASEAN Economic Community (AEC), which is an ASEAN region integration, which could turn ASEAN countries to become more attractive to investors. AEC is the realization of the economic integration goal that is espoused in Vision 2020. It is based on the interest convergence of ASEAN member countries to broaden and deepen the integration of economy through new and existing initiatives supported with a clear deadline. As a result of this, the competition for human resources and business competition will be much stronger than before.

Value-Added Intellectual Capital (VAIC) method initiated by Pulic (2000) is used in measuring intellectual capital. The reason why VAIC is chosen because it is the most popularly used method in the studies related to intellectual capital (Firer and Williams, 2003; Yu et al. 2010; Maditinos et al. 2011; Latif et al. 2012).
Pulic argued that one of the reasons that VAIC is a better approach in intellectual capital measurement is that it offers comparability among sectors, companies, and countries. Many previous studies have been done on intellectual capital; however, the results vary. Some of the research found a positive relationship of VAIC towards market value and financial performance (Chen et al. 2005; Chu et al. 2011; Latif et al. 2012; Feimianti and Anantadjaya, 2014; ). On the other hand, some of the research failed to discover such correlation between VAIC and market value and financial performance. Firer and Williams (2003) failed to find a significant correlation between them. The result is limited and mixed. In spite of the efforts to improve its intellectual capital resources, it is shown that South African market still puts prominent value and weight in physical assets.

The aim of this paper is to do empirical analysis on the effect of intellectual capital - measured using VAIC methodology initiated by Pulic (2000) on corporate's financial performance, more specifically on the market value, profitability and productivity. There have been many studies investigating the correlation between intellectual capital and firms' financial performance. Thus, this research would like to dig more whether intellectual capital contributes to firm's market value and firm's financial performance in Indonesian manufacturing listed companies. It is hoped that there will be better understanding of how the role of intellectual capital in the today's emerging economy could be achieved.

An empirical study conducted by Feimianti and Anantadjaya (2014) was one of the examples of intellectual capital's impact on financial performance research in Indonesia. It's also using the same VAIC approach with the five-year period observation from published annual reports of listed companies as the source of data for its empirical study. The main difference is located in the population chosen as the focus study. While Feimianti and Anantadjaya's research (2014) was focusing on consumer goods industry in Indonesia, this research is focusing on the bigger scope of manufacturing industry in Indonesia as a whole. Manufacturing industry in Indonesia is chosen as the observation object of author's study because manufacturing industry itself is known as the laborintensive industry where skills are important, such as in machine operations. Thus, it will be interesting to see whether the role of intellectual capital and 
the management of it by manufacturing companies will impact to the firms' market value and financial performance. Manufacturing industry in Indonesia could be said as one of the biggest industries, and from Table 1 it can be seen that manufacturing industry has big contribution towards Indonesian economy. On top of that, it's reported that based on the United Nations Industrial Development (UNIDO) statistical report of International Yearbook of Industrial Statistics 2016, Indonesia is included in the top ten manufacturers of the world (Amindoni, 2016).

Table 1. Contribution of Manufacturing Industry to Indonesian Economy (GDP)

\begin{tabular}{cc}
\hline Year & Contribution \\
\hline 2009 & $26.35 \%$ \\
2010 & $24.79 \%$ \\
2011 & $24.32 \%$ \\
2012 & $23.97 \%$ \\
2013 & $21.03 \%$ \\
2014 & $21.01 \%$ \\
2015 & $20.84 \%$ \\
\hline
\end{tabular}

Source: Bisnis Indonesia Newspaper (Hidayat, 2016)

The remainder of this paper is arranged into four sections. The second section covers a literature review of the variables together with the underlying theory and hypothesis. The third section explains the research methodology of this research study. The fourth section will cover research result, analysis, and discussion. The last section will give the summary of research findings together with the suggestions for future research.

In resource-based view, firms' resources are regarded as the main driver or factor that drives firms' competitiveness and firms' performance. It includes both tangible and intangible assets that are being utilized effectively and efficiently to implement competitive strategies. It's described that firms attain sustainable competitive advantage and achieve profits by owning and controlling both tangible assets and intangibles assets. It highlights that firms' resource plays a role as the fundamental determining factor of firms' competitive advantage. The firm resource must be rare, valuable and imperfectly substitutable and imitable to be a sustainable competitive advantage source (Barney, 1991). Distinctive resources, competence, and capabilities will be firm's core competency, thus will present a competitive advantage. According to Hitt et al. (2001), intangible resources, especially intangiblefirm specialties such as knowledge, will more likely generate competitive advantage and value added compared to tangible assets.

\section{METHODS}

This research uses Multiple Linear Regression with the basis of Ordinary Least Square. Multiple Linear Regressions are used in this research because there are several independent variables observed towards the dependent variables. The research population was all listed manufacturing companies in Indonesian Stock Exchange (IDX) in 2015 with the total of 142 companies. There were sample criteria set in this research. First, as the observation was the five-year period from 2011-2015, thus, the sample companies should have a complete annual report for those five years. Second, its annual report figure should be in Rupiah currency. Third, its financial statements should show a complete one-year figure. The data used in this research was all secondary data taken mainly from Bloomberg database. Several incomplete data were double-checked and obtained from the annual report in Indonesian Stock Exchange (IDX). There were ten regression models analyzed by using SPSS to assess all the relationships of independent and dependent variables as shown in the Table 2 .

The research performed analysis on the relationship between dependent and independent variables as shown below: VAIC, Human Capital Efficiency, Structural Capital Efficiency, Capital Employed Efficiency are the independent variables; Market value and financial performance (ROA, ROE, Growth Revenue, Asset Turnover) are the dependent variables; Firm Size and leverage are the control variables. Research model in Figure 1.

The definition of intellectual capital may vary over the years. Intellectual capital (IC) is the combination of intangible assets such as intellectual property, market, human-centered and infrastructure, in which these factors will play a supportive role for the company to function well (Brookings, 1996). IC is also viewed as a knowledge-based system of intangible resources and activities that have dynamic characteristics, and it also becomes the main factor that drives value creation (Lev, 2003). It actually could be identified as the economic value as perceived from three intangible assets namely 
human capital, organizational capital and social capital (Choudhury, 2010). IC is widely accepted as a major corporate strategic asset which has a crucial role in creating the competitive advantage that is sustainable and positive financial performance (Barney, 1991). IC is also viewed as a firm's hidden value that is not reflected in the firm's published financial reports, where it could act as firms' competitive advantage (Edvinson and Malone, 1997; Chen et al.2005). Limitation in the published financial reports inaccurately describing a real firm value shows that in fact, an economic value source in today economy is no longer about material goods production but more into intellectual capital generation (Chen et al. 2005).
In spite of increasing acknowledgment of the importance of intellectual capital in creating a firm value and how it has gained importance as the main resource for firms to sustain and develop firms' competitive advantages, the measure of firm's intellectual capital is still in the early stage. However, as the understanding and research of intellectual capital's impact on firm performance increases, so does the method and measurement on it. Through years, various efforts have been done both by researchers and practitioners to evaluate intellectual capital. Then, in recent past years, many researchers (Chen et al. 2005; Tan et al. 2007; Wang, 2011) have investigated in the area of the intellectual capital and its implications on organizational performance based on different markets and different industries.

Table 2. Equation formulas

\begin{tabular}{|c|c|}
\hline Models & Regression Equations \\
\hline Model 1 & $\mathrm{MBRat}=\mathrm{a}_{0}+\mathrm{a}_{1} \mathrm{VAIC}+\mathrm{SIZE}+\mathrm{LEV}+\mathrm{e}$ \\
\hline Model 2 & $\mathrm{ROA}=\mathrm{a}_{0}+\mathrm{a}_{1} \mathrm{VAIC}+\mathrm{SIZE}+\mathrm{LEV}+\mathrm{e}$ \\
\hline Model 3 & $\mathrm{ROE}=\mathrm{b}_{0}+\mathrm{b}_{1} \mathrm{VAIC}+\mathrm{SIZE}+\mathrm{LEV}+\mathrm{e}$ \\
\hline Model 4 & $\mathrm{GR}=\mathrm{c}_{0}+\mathrm{c}_{1} \mathrm{VAIC}+\mathrm{SIZE}+\mathrm{LEV}+\mathrm{e}$ \\
\hline Model 5 & $\mathrm{ATO}=\mathrm{d}_{0}+\mathrm{d}_{1} \mathrm{VAIC}+\mathrm{SIZE}+\mathrm{LEV}+\mathrm{e}$ \\
\hline Model 6 & $\mathrm{MBRat}=\mathrm{a}_{0}+\mathrm{a}_{1} \mathrm{HCE}+\mathrm{a}_{2} \mathrm{SCE}+\mathrm{a}_{3} \mathrm{CEE}+\mathrm{SIZE}+\mathrm{LEV}+\mathrm{e}$. \\
\hline Model 7 & $\mathrm{ROA}=\mathrm{a}_{0}+\mathrm{a}_{1} \mathrm{HCE}+\mathrm{a}_{2} \mathrm{SCE}+\mathrm{a}_{3} \mathrm{CEE}+\mathrm{SIZE}+\mathrm{LEV}+\mathrm{e}$ \\
\hline Model 8 & $\mathrm{ROE}=\mathrm{b}_{0}+\mathrm{b}_{1} \mathrm{HCE}+\mathrm{b}_{2} \mathrm{SCE}+\mathrm{b}_{3} \mathrm{CEE}+\mathrm{SIZE}+\mathrm{LEV}+\mathrm{e}$ \\
\hline Model 9 & $\mathrm{GR}=\mathrm{c}_{0}+\mathrm{c}_{1} \mathrm{HCE}+\mathrm{c}_{2} \mathrm{SCE}+\mathrm{c}_{3} \mathrm{CEE}+\mathrm{SIZE}+\mathrm{LEV}+\mathrm{e}$ \\
\hline Model 10 & $\mathrm{ATO}=\mathrm{d}_{0}+\mathrm{d}_{1} \mathrm{HCE}+\mathrm{d}_{2} \mathrm{SCE}+\mathrm{d}_{3} \mathrm{CEE}+\mathrm{SIZE}+\mathrm{LEV}+\mathrm{e}$ \\
\hline
\end{tabular}

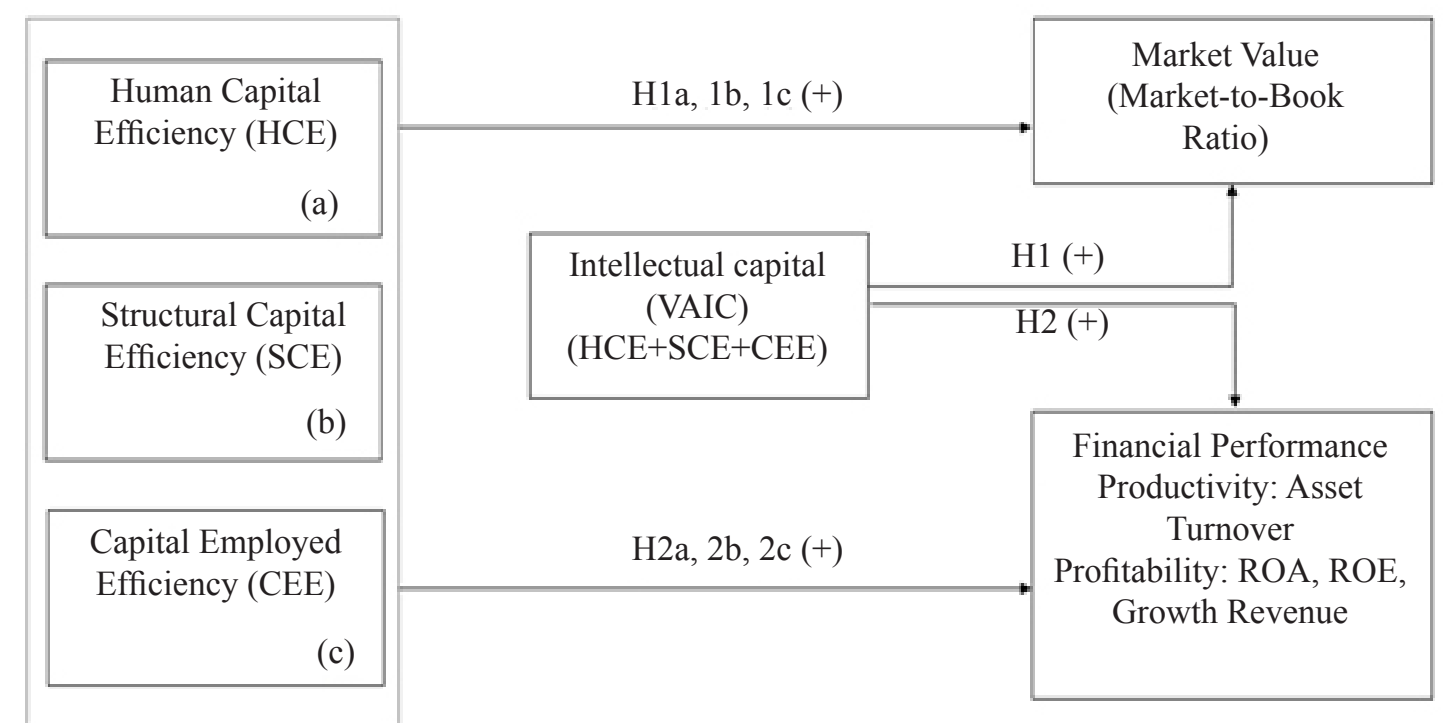

Figure 1. Research model 
Among many intellectual capital measurement methods that have been developed, Pulic (1998) has developed and introduced Value Added Intellectual Coefficient (VAICTM) where it uses firms' financial reports to compute the efficiency coefficient of human capital, structural capital and capital employed. This VAIC method has popularly been used to measure intellectual capital and its component's efficiency based on the value-added concept. This method has been increasingly used in intellectual capital research these past years, in which some showed positive relationship but some others failed to find the relationship (Firer and Williams, 2003; Chen et al. 2005; Tan et al. 2007).

VAIC model measures how the organization creates value added (VA). In the Pulic model, labor or employees are treated as a value creating the entity (MD, 2008). VA itself is highly influenced by Human Capital efficiency (HCE) and Structural Capital efficiency (SCE) and capital employed Efficiency (CEE). Below are the five steps in calculating VAIC:

\section{Calculate the Value Added (VA) \\ $\mathbf{V A}=\mathbf{O U T}-\mathbf{I N}$}

Where OUT is the overall total sales and other income; IN is sales expenses and other expenses.

Capital Employed Efficiency (CEE) represents ratio from VA to CE. This ratio will show contribution made from each unit of $\mathrm{CE}$ to the value added of the firm.

\section{$\mathrm{CEE}=\mathrm{VA} / \mathrm{CE}$}

Human Capital Efficiency (HCE) represents ratio from VA to HC. This ratio will show the contribution from each rupiah spent on $\mathrm{HC}$ to firm value added.

\section{$\mathrm{HCE}=\mathrm{VA} / \mathrm{HC}$}

Structural Capital Efficiency (SCE) represents all the conditions which enable human resources to produce the added value for the company. It is measured by the remaining value of the value-added after subtracted with human capital figures.

\section{SCE $=$ VA-HC}

Value Added Intellectual Coefficient (VAIC) indicates the extent of corporate intellectual ability.
VAIC as a method for intellectual capital measurement has the comparability, reliability, and simplicity, which make it an appropriate measure in the context of the present research study.

Human capital represents individual's knowledge, motivation, and competencies that an employee possesses to support business performance and it also could be said as the basic resource that the organization has (Bontis et al. 2001). Employees are considered as one of the company's most important assets, especially in a learning organization. Human capital denotes human resources in regards to employees' required competencies, such as knowledge, skills and other personal attributes (McGregor et al. 2004). In today business environment, human capital is recognized as a companies' critical asset and also acts as the value creator. Human capital is regarded as a vital source for companies' competitive advantage. A human capital value is not reported adequately to stakeholders partially owing to strict criteria for intangible assets' recognition which prevent human resources to be shown as an asset on the balance sheet (Tayles et al. 2007). The information related to any activities and decisions made by the key personnel that contribute to competitive advantage and "hidden" value for the companies is often not disclosed, so that analysts need to incur extra cost to seek private information on the "value creators" in the companies. Human capital is measured by total expenditures that company spent on its human capital. To cope with VAIC approach, this research will look at the efficiency of its human capital, and also look at its value added.

Structural capital is the expertise or 'know-how' that belongs to the firm's property after the contribution induced by the human skill (Bontis, 1998). Some examples of structural capital established by the employees' competencies are the organizational systems, cultures, procedures, as well as the general use of information technology and organizational learning capacity. Structural capital is what belongs to the firms, including innovative capital, relational capital, and organizational infrastructure, etc. (Roos et al. 1997). Structural capital is measured by the remaining value of the value-added after subtracted with human capital figures. This measurement will be the same for all studies that use VAIC measurement method (Pulic, 2000; Chen et al. 2005; Chan, 2009). 
VAIC method is being used in this research. Following its concept, relational capital is being replaced with capital employed. This is because the relationship between customers and product or service that is viewed only determines the value (Feimianti and Anantadjaya, 2014). Moreover, due to the limited space, in Pulic's model, only two basic elements of intellectual capital are included, namely human and structural capital. The measurement of capital employed itself is varied. Some of the research measured it by the book value of fixed net asset (Firer and Williams, 2003; Yu et al. 2010). Muhammad and Ismail (2009) are subtracting the total assets with the intangible asset figure. However, considering not all manufacturing companies have disclosed the intangible figure in their annual reports, this research uses the capital employed formula from ACCA Paper F9 Module on financial management (BPP, 2015) which adds the shareholders' equity with the total debt.

Market-Based Measures include rates or ratios that incorporate the organization's market value. The measures include the return to stakeholders, market value added, holding period returns, Tobin's $\mathrm{Q}$ and market-to-book value ratio. The information or data required to achieve these measures are usually available for firms that are publicly traded and have market value. Market value usually reflects the real value of the company, and it's usually higher than company's book value. To measure the market value, the marketto-book ratio will be used in this research. Marketto-Book (MBR) value is the ratio of the total market capitalization to book value of net assets.

Market-to-Book Ratio $=($ Market Value $) /($ Book Value $)$ Market Value $=$ No.Of an outstanding shares $\mathrm{x}$ Stock price at year end

Book Value $=$ Shareholders'Equity - Paid in capital of preferred stocks

Sveiby (2010) argued traditional accounting practices failed to consider intellectual capital as one of the most vital intangible assets of every organization. Besides, according to IFRS, gradual introduction of International Accounting Standard in mostly all developed and developing countries, has indirectly required companies to assess their assets at real market value, while providing full definition and credit to intangibles. However, such implementation is costly, and not all companies can comply with that requirement, which has impacted to the deterioration of intangible asset recognition. Thus, we could see growing gap between market and firm's book value. This present paper will like to see whether intellectual capital will have a significant effect on the market value of the companies through the hypothesis below:

\section{H1: Companies with greater IC have higher ratios of} market-to-book value.

H1a: Companies with greater human capital efficiency have higher ratios of market-to-book value.

H1b: Companies with greater structural capital efficiency have higher ratios of market-to-book value.

H1c: Companies with greater capital employed efficiency have higher ratios of market-to-book value.

Financial performance is a measure of a firm ability to utilize its assets from its primary business activities and generate income and profit (Al-Matari et al. 2014). In this present paper, two big indicators of financial performance will be used. First is profitability. By having profits, an organization will be able to provide the return to the equity capital providers (Bidaki and Hejazi, 2014). Without profits and its likely prospects, it will result in the providers' capital withdrawal of their investment from the organization. Second is the productivity. The second measurement sees how efficient the company uses its resources to turn them into sales. Below are several financial performance indicators that will be used:

ROA: It reflects firms' efficiency in utilizing its total assets to generate revenue.

$$
\mathrm{ROA}=(\text { Net Income }) /(\text { Total Assets })
$$

ROE: It represents shareholders' returns, and is considered as one of the important financial indicators for investors.

$$
\mathrm{ROE}=(\text { Net Income }) /(\text { Shareholders' Equity })
$$

Growth in Revenue (GR): It measures the changes in firms' revenues, where revenue increase is signaling growth opportunity of the firms.

$$
G R=\left[\left(\frac{\text { Current year's revenue }}{\text { Last year's revenue }}\right)-1\right] \times 100 \%
$$


Asset Turnover: It will be used to measure how efficient the company uses its asset to generate sales.

$$
\mathrm{ATO}=(\text { Total Revenue }) /(\text { Total Assets })
$$

Many types of research have been done nationally and internationally on intellectual capital impacts towards financial performance. No significant correlation was found towards ROA and ROE on South African listed companies (Firer and Williams, 2003). A study over wood manufacturer SMEs of Oberá (Argentina) shows a result that only structural capital directly affected the firm performance, while the other two, human capital and relational capital, were fully mediated by the structural capital of the company (Jardon and Martos, 2009). Thus, further observation on these variables' relationship will be conducted through the second hypothesis below:

H2: Companies with greater IC have better financial performance.

H2a: Companies with greater human capital efficiency have better financial performance.

H2b: Companies with greater structural capital efficiency have better financial performance.

H2c: Companies with greater capital employed efficiency have better financial performance.

\section{RESULTS}

This research study was focused on the relationship between two main dependent variables, companies' market value and the financial performance which were supported by four selected indicators, ROA, ROE, revenue growth, and asset turnover. The ten regression models firstly went through the four (or three?) classical assumption tests, i.e. normality test (KolmogorovSmirnov), multicollinearity test, and heteroscedasticity test (Glejser and Spearman). The sample data initially comprised of 465 firm-year observations. However, it couldn't pass the normality test, so the author did further data screening and eliminated some outliers. As a result, there were 320 firm-year observations as the remaining samples. With the 320 observations, all the regression models successfully passed the normality tests $(\mathrm{p}>0.05)$ and multicollinearity test (VIF $<10$; TOL $>5 \%)$. There was no heteroscedasticity problem found in the regression. Therefore, all the 320 samples were valid and qualified for hypothesis testing. The result of t-test (hypothesis testing) for ten regression model used in the study was mixed. The details of the results could be seen in Table 3 .

By observing the results showed in Table 4, it could be concluded that only three out of eight hypotheses are accepted. Below are the description and explanation of the regression result from each accepted hypothesis. Capital employed Efficiency (CEE) has a significant value of $0.001(\mathrm{p}<0.05)$ with $\beta$ of 0.198 towards market value, while CEE has the average significant value of 0.004 and average $\beta$ value of 1.116 towards financial performance. This means CEE has an overall positive significant correlation towards market value and all selected financial performance indicators. Thus, H1c and H2c are accepted. Gan and Saleh (2008) consistently found CEE to have significant correlation towards market value and selected indexes of financial performance. It indicates that in Indonesia, most of the manufacturing industry companies still rely greatly on physical capital efficiency (greater value in physical assets is put over intellectual capital assets).

Table 3. Summary of T-test result (Hypothesis Testing)

\begin{tabular}{lll}
\hline $\begin{array}{l}\text { Independent } \\
\text { Variable }\end{array}$ & $\begin{array}{l}\text { Dependent } \\
\text { Variable }\end{array}$ & Correlation \\
\hline VAIC & MBRAT & Insignificant \\
& ROA & Positive Significant \\
& ROE & Positive Significant \\
& GR & Positive Significant \\
& ATO & Positive Significant \\
HCE & MBRAT & Insignificant \\
& ROA & Insignificant \\
& ROE & Insignificant \\
& GR & Positive Significant (at \\
& & $\alpha=10 \%)$ \\
SCE & ATO & Insignificant \\
& MBRAT & Negative Significant \\
& ROA & Insignificant \\
& ROE & Insignificant \\
& GR & Insignificant \\
& ATO & Negative Significant \\
CEE & MBRAT & Positive Significant \\
& ROA & Positive Significant \\
& ROE & Positive Significant \\
& GR & Positive Significant \\
& ATO & Positive Significant \\
\hline & &
\end{tabular}


Table 4. Regression results

\begin{tabular}{|c|c|c|c|c|c|c|c|c|c|c|c|c|c|c|c|}
\hline Dependent & & MBRAT & & & ROA & & & ROE & & & GR & & & ATO & \\
\hline Independent & Coeff & t-stat & Sig. & Coeff & t-stat & Sig. & Coeff & t-stat & Sig. & Coeff & t-stat & Sig. & Coeff & t-stat & Sig. \\
\hline Constant & -7.161 & -10.569 & 0.000 & -0.132 & -2.606 & 0.01 & -0.231 & -2.542 & 0.011 & 3.551 & 0.204 & 0.839 & 1.712 & 4.223 & 0,000 \\
\hline VAIC & 0.002 & 1.065 & 0.288 & 0,000 & 2.253 & 0.025 & 0.001 & 3.709 & 0,000 & 0.144 & 3.218 & 0.001 & 0.009 & 8.553 & 0,000 \\
\hline FIRMSIZE & 0.297 & 12.12 & 0.000 & 0.006 & 3.483 & 0.001 & 0.011 & 3.293 & 0.001 & 0.034 & 0.053 & 0.958 & -0.032 & -2.181 & 0.03 \\
\hline LEVERAGE & -0.078 & -2.589 & 0.01 & -0.013 & -5.736 & 0,000 & -0.023 & -5.686 & 0,000 & 1.49 & 1.928 & 0.055 & 0.019 & 1.07 & 0.286 \\
\hline $\begin{array}{l}\text { Adjusted R } \\
\text { Square }\end{array}$ & 0.317 & & & 0.111 & & & 0.127 & & & 0.039 & & & 0.191 & & \\
\hline F-Value & 50.436 & & & 14.325 & & & 16.436 & & & 5.366 & & & 26.082 & & \\
\hline Constant & -7.353 & -10.799 & 0.000 & -0.18 & -3.605 & 0.000 & -0.362 & -4.249 & 0,000 & -3.11 & -0.175 & 0.861 & 0.56 & 2.499 & 0.013 \\
\hline HCE & 0.001 & 0.48 & 0.631 & -3.516 & -0.234 & 0.815 & -3.788 & -0.148 & 0.882 & 0.101 & 1.885 & 0.06 & 0.001 & 1.585 & 0.114 \\
\hline SCE & -0.903 & -2.715 & 0.007 & -0.015 & -0.626 & 0.532 & -0.02 & -0.476 & 0.634 & -5.857 & -0.675 & 0.5 & -0.385 & -3.519 & 0,000 \\
\hline CEE & 0.198 & 3.249 & 0.001 & 0.023 & 5.234 & 0.000 & 0.061 & 8.007 & 0,000 & 3.815 & 2.398 & 0.017 & 0.565 & 28.161 & 0,000 \\
\hline FIRMSIZE & 0.325 & 12.86 & 0,000 & 0.008 & 4.267 & 0.000 & 0.014 & 4.564 & 0,000 & 0.349 & 0.529 & 0.597 & 0.006 & 0.67 & 0.503 \\
\hline LEVERAGE & -0.106 & -3.446 & 0.001 & -0.016 & -7.218 & 0.000 & -0.032 & -8.273 & 0,000 & 0.947 & 1.177 & 0.24 & -0.063 & -6.266 & 0,000 \\
\hline $\begin{array}{l}\text { Adjusted R } \\
\text { Square }\end{array}$ & 0.344 & & & 0.176 & & & 0.27 & & & 0.05 & & & 0.765 & & \\
\hline F-Value & 34.432 & & & 14.663 & & & 24.542 & & & 4.328 & & & 208.67 & & \\
\hline
\end{tabular}

This may be true because, in Indonesian manufacturing industry, most companies will put higher investments and a bigger number of machines as one of their prominent assets as their main activities mostly deal with the production of goods. More intense activities are done with the machinery, compared to human capital and structural capital.

Intellectual capital (VAIC) has an average significant value of 0.0065 and average $\beta$ value of 0.039 towards financial performance. The finding means VAIC has significant positive correlation towards all selected indicators which are ROA, ROE, revenue growth and asset turnover. Thus, hypothesis $\mathrm{H} 2$ is accepted. The finding suggests the importance of firms' efficiency in using financial, physical, structural, and human capital effectively and efficiently to create bigger companies' profitability and productivity. This finding is similar with Gan and Saleh's (2008) who also found significant correlation between VAIC and the company financial performance measured by ROA and ATO, which explains that when an intellectual capital efficiency of the company increases, then it is expected that profitability and productivity of that company will also increase.

Below are the description and explanation of the regression result from another five hypotheses that are rejected. Intellectual capital (VAIC) has a significance level of $0.288(p>0.05)$ with $\beta$ value of 0.002 to market value. The finding indicates an insignificant correlation was found between VAIC and market value. Thus, the $\mathrm{H} 1$ is not acceptable, as it can't be proved that higher intellectual capital efficiency leads to higher market value. The finding is explainable with the views of Holland and Johanson (2003), who suggests that market valuation is based on investors' investment decision in selecting and valuing the company, as different values could be put on firms' performance that may or may not include IC. Chan (2009), also found there was no significant relationship between IC and market value which meant that there might be a discrepancy among investors in terms of the level of awareness on IC importance in companies' value creation, as this possibly exists in different countries, different capital markets. It is arguable that it is also influenced by maturity level of IC awareness found in investors in a specific market.

Human capital efficiency (HCE) has significance level of 0.631 ( $p>0.05$ ) with $\beta$ value of 0.001 to market value. The finding means that no significant correlation was found between HCE and market value. Thus, $\mathrm{H} 1 \mathrm{a}$ is rejected. This is in line with the findings by Morris (2015) who fails to find a correlation between HCE and market-to-book value in listed companies in South Africa. The result is explained by the views of Gan and Saleh (2008), investors' perceptions as a whole could drive market behavior in emerging market (i.e. Indonesian market is categorized as emerging market). Generally in emerging stock markets, market sentiment is more influential on share prices than 
fundamental analysis of market behavior. Even though the market appears to put high attention for human capital assets, it shows insights of the possibilities that the market acts negatively if the firm concentrates on enhancing human resources at the expense of physical capital asset development. It is justifiable considering the object observed in this research is manufacturing companies. The finding holds true considering the nature of manufacturing industry, where the primary business activity is producing goods and highly deals with physical assets such as machinery, implying that in this industry less emphasis was put on human capital, compared to the physical asset. The result is supported by another finding in this research; CEE has higher positive significant correlation towards market value.

Structural capital efficiency (SCE) has a significance level of $0.007(p<0.05)$ towards market value. However, it has a negative correlation ( $\beta$ value of -0.903 ). The finding means companies that have a bigger efficiency in their structural capital will have a lower market value. Thus, the hypothesis H1b is rejected. This is similar to the findings on Chan (2009) who found a significant negative association between HCE and market value, which signified that investors had a negative view that company had higher employee-related expenditures than their investment in physical capital. The same thing might be applied to these SCE findings, signaling that for manufacturing companies, the investors do not seem happy if the company spends too much on expenditures of internal structural capital investments compared to the physical capital investments. This happens since CEE is the only VAIC element which proved to have a significant positive influence towards market value. It could also imply that investors tend not to place more value or emphasis over the structural capital of the companies. Besides, Huang and Liu (2005) pointed out that there is a non-linear relationship (inverted U-shape) between innovation capital and business performance, indicating that when a company puts more investment in innovation capital, better financial performance can be achieved. However, when the investment exceeds the optimal level, then this investment will give negative influence towards business performance, once the company spends too much on it. Then, it will impact adversely on the firm performance. The Higher cost will be incurred, which will affect the company profitability. If the profitability is affected negatively, the investors might not be too happy, and thus, market value will drop.
Of the four selected financial performance indicators, only HCE (Human Capital Efficiency) to GR that is found to be positively significantly correlated (with $\alpha$ $=10 \%$ ). Additionally, the correlation for the rest three indicators proved to be insignificant. HCE is found to be only positively correlated towards growth revenue; it is because in boosting the sales of the company, the sales force/sales people of the company hold the crucial role. Thus, if there is high efficiency in managing its human capital (such as training and development of the sales people), it will impact to the increase in the sales of the company. When the company's HCE is high, then the revenue growth will increase as well. Thus, hypothesis $\mathrm{H} 2 \mathrm{~b}$ is rejected. The result is similar to the findings by Huang and Hsueh (2007), which show that human capital has the poorest performance compared to the other IC components, which indicates that in Taiwan engineering consulting firms give little prominence to human resource management. This might hold true in manufacturing industry context as more emphasis is put on physical assets like machinery and warehouses, compared to human capital.

Structural capital efficiency (SCE) was found to have insignificant relationship towards ROA, ROE, and GR (profitability indexes) with the significance value of $0.532,0.634$ and 0.5 respectively $(p>0.05)$, which means that greater structural capital efficiency has no influence on the profitability of the company. However, it is found to have a significant negative correlation towards productivity (ATO) with the significance level of $0.000(p<0.05)$ and $\beta$ value of -0.385 . It is concluded that overall there is no correlation between SCE and financial performance. Thus, hypothesis $\mathrm{H} 2 \mathrm{~b}$ is rejected. This might be explained by looking at the nature of manufacturing industries, where physical capital might be more dominant as the business operation is highly related to the machinery. Thus, when the company spent more on enhancing its internal structural capital and put more focus on it, it might affect the productivity of the company, because the company put less investment in its physical capital such as machinery.

Overall, $70 \%$ of regression models shows that the control variables, Firm Size and Leverage, have a significant influence, while the rest $30 \%$ shows no significant relationship. Firm size has a positively significant relationship in these models, which indicates that firm size does affect the market value and financial performance of the company (except for Model 4, 9, 10). A big company will likely have a better market 
value and financial performance compared to a small one. However, as three out of ten regression models that have been running show no significance towards several financial performance indicators, not all big companies will have a better financial performance such as growth in revenue and asset turnover. The other factors such as the efficiency and effectiveness of the company managing its resources, business process, and sales execution should be taken into further consideration.

Leverage has a negatively significant relationship in these models (except for Model 5, 9), it has a different relationship towards the market value and financial performance indicators. It seems that a bigger firms' debt structure will impact adversely towards the market value and financial performance of the company. It is justified by Williams (2000), who stressed that a higher proportion of debt can divert the company to focus more on the debt holders' needs. This is inconsistent with one of the VAIC main supported theories, which is the stakeholder's view. It is seen that when a company has a high reliance on debt, then there will be an insufficient required security for attracting investors. With higher debt, the company is more likely to have higher interest payments, reflecting upon the greater risk exposure and the return of the firms. Besides, it is said that the firms' ability to invest in the intellectual capital could be possibly deterred with the existence of debt covenants and interest costs. It is because company's focus could be diverted more towards debt holders and interest cost payments rather than towards investment in intellectual capital.

\section{Managerial Implication}

From the analysis above, it can be concluded that for the companies, it is better to put more attention towards its intellectual capital as can be seen from the research result that it could actually improve the firms' financial performance which in long term could affect better firms' value in the market as well. It is also good for the companies to give updates and more disclosures on how the companies do the intellectual capital management.

\section{CONCLUSIONS AND RECOMMENDATIONS}

\section{Conclusions}

Overall, the empirical findings are mixed in proving the correlation between intellectual capital which is measured by VAIC towards market value, profitability, and productivity. It is proved that CEE consistently has positively significant relationship towards both market value and selected financial performance (profitability and productivity). The result indicates that in Indonesian manufacturing industry, most of the companies still have a high dependency on the physical capital resource; most companies will put higher investments and a bigger number of machines as one of its prominent assets as their main activities mostly dealing with the production of the goods.

\section{Recommendations}

Future research may use another methodology in valuing intellectual capital to see whether another method has better explanatory power on an intellectual capital, or maybe with the establishment of linkage with intangible assets. In IAS 38 about intangible assets (IFRS), things like R\&D cost, patents, copyrights and goodwill are classified as intangible assets, in which some parts of intangible assets might be able to link with intellectual capital, indicating that the linkage of intangible assets and intellectual capital could become an additional development to current available measurement of intellectual capital, helping to explain the gap between market value and book value of the company.

The result of insignificant HCE correlation towards both market value and financial performance of the company is mainly driven by the nature of the industry observed in this research, which is manufacturing. In manufacturing companies, investors will put more emphasis on physical capital compared to human capital, because most manufacturing companies mainly deal with physical assets such as machinery as their main business activities in producing the goods. Thus, future research can be done on an empirical analysis on other industries to see whether different results and explanation can be obtained (Yu et al., 2010; Morris, 2015; Gan and Saleh, 2008).

\section{REFERENCES}

Al-Matari EM, Al-Swidi AK, Fadzil, FHB. 2014. The measurements of firm's performance's dimensions. Asian Journal of Finance and Accounting 6(1): 24-49. https://doi.org/10.5296/ ajfa.v6i1.4761.

Amindoni A. 2016. Indonesia one of the world's top 10 
manufacturers. http://www.thejakartapost.com/ news/2016/04/21/indonesia-one-of-the-worldstop-10-manufacturers.html. [2016 April 21]

Barney J. 1991. Firm Resources and Sustainable Competitive Advantage. Journal of Management 17(1): 99-120. https://doi. org/10.1177/014920639101700108.

Bidaki S, Hejazi R. 2014. Effects of profitability on the Intellectual Capital Disclosure in listed Companies in Tehran Stock Exchange. International journal of education and applied sciences 1(5): 248-255.

Bontis, N. 1998. Intellectual capital: an explanatory study that develops measures and models. Management Decision 36 (2): 63-76.https://doi. org/10.1108/00251749810204142.

Bontis N, Crossan MM, Hulland J. 2001. Managing an organizational learning system by aligning stocks and flows. Journal of Management Studies 39(4):437-469. https://doi.org/10.1111/14676486.t01-1-00299

BPP. 2015. Financial Management (p. 19). London: BPP Learning Media Ltd.

Brookings A. 1996. Intellectual Capital - Core Asset for the Third Millenium Enterprise. London: Thomson Learning.

Chan K. 2009. Impact of Intellectual Capital on Organisational Performance: An Empirical Study of Companies in the Hang Seng Index (Part 2). The Learning Organization 16 (1): 22-39. https://doi.org/10.1108/09696470910927650.

Chen MC, Cheng SJ, Hwang Y. 2005. An empirical investigation of the relationship between intellectual capital and firms' market value and financial performance. Journal of Intellectual Capital 6(2): 159-176. https://doi. org/10.1108/14691930510592771.

Choudhury DJ.2010. Performance impact of intellectual capital: a study of Indian IT sector. International Journal of Business and Management 5 (9): 72 80. https://doi.org/10.5539/ijbm.v5n9p72.

Chu S, Chan K, Wu, W. 2011. Charting intellectual capital performance of the gateway to China. Journal of Intellectual Capital 12 (2): 249-276. https://doi.org/10.1108/14691931111123412.

Edvinson L, Malone MS. 1997. Intellectual Capital: Realizing Your Company's True Value by Finding Its Hidden Brainpower. New York: Harper Business.

Feimianti E, Anantadjaya S. 2014. Value Creation of Intellectual capital: financial performance analyses in Indonesian publicly-listed consumer goods industry. Review of Integrative Business and Economics Research 3(1): 99-113.

Firer S, Williams W. 2003. Intellectual capital and traditional measures of corporate performance. Journal of Intellectual Capital 4(3): 348-360. https://doi.org/10.1108/14691930310487806.

Gan K, Saleh Z. 2008. Intellectual capital and corporate performance of technology-intensive companies: Malaysia evidence. Asian Journal of Business and Accounting 1(1): 113-130.

Hitt M, Bierman L, Shimizu K, Kochhar R. 2001. Direct and Moderating Effects of Human Capital on Strategy and Performance in Professional Service Firms: A Resource-Based Perspective. Academy of Management Journal 44 (1): 13-28.

Holland J, Johanson U. 2003. Value-relevant information on corporate intangiblescreation, use and barriers in capital markets'between a rock and a hard place'. Journal of Intellectual Capital 4(4): 465-485. https://doi. org/10.1108/14691930310504518.

Huang C, Liu C. 2005. Exploration for the relationship between innovation, IT and performance. Journal of Intellectual Capital 6(2): 1469-1930.

Huang CF, Hsueh SL. 2007. A Study on the relationship between intellectual capital and business performance in the engineering consulting industry: A Path Analysis. Journal of Civil Engineering and Management 13(4): 265-271. https://doi.org/10.3846/13923730.2007.963644 6.

Huffman N. 2012. Knowledge: Concepts in Knowledge Management: Part Three. http://www.examiner. com/article/concepts-knowledge-managementpart-three. [15 November 2016]

Jardon CM, Martos S. 2009. Intellectual capital and performance in wood industries of Argentina. Journal of Intellectual Capital 10(4): 1469-1930. https://doi.org/10.1108/14691930910996670.

Latif M, Shoukat MM, Aslam S. 2012. Intellectual Capital Efficiency and Corporate Performance in Developing Countries: A Comparison Between Islamic and Conventional Banks of Pakistan. Interdisciplinary Journal of Contemporary Research in Business 4(1): 405-420.

Lev SZ. 2003. Intangibles and Intellectual Capital: an introduction to a special issue. European Accounting Review 12 (4): 597-603. https://doi. org/10.1080/0963818032000162849.

Maditinos D, Chatzoudes D, Tsairidis C, Theriou G. 
2011. The impact of intellectual capital on firms' market value and financial performance. Journal of Intellectual Capital 12(1): 132-151. https:// doi.org/10.1108/14691931111097944.

MD, IU. 2008. Intellectual capital performance sektor perbankan di Indonesia. Jurnal Akuntansi dan Keuangan 10(2): 77-84.

Morris C. 2015. An industry analysis of the power of human capital for corporate performance: evidence from South Africa. South Africa Journal Economy Management Science 18(4): 486-499. https://doi.org/10.4102/sajems.v18i4.1191.

Muhammad N, Ismail M. 2009. Intellectual capital efficiency and firm's performance: Study on Malaysian financial sectors. International Journal of Economics and Finance 1(2): 206212. https://doi.org/10.5539/ijef.v1n2p206.

Pulic A. 1998. Measuring the performance of intellectual potential in the knowledge economy. The 2nd World Congress on the Management of Intellectual Capital, Hamilton, January 21--23.

Pulic A. 2000. VAIC - an accounting tool for IC management. International Journal of Technology Management 20(5-8): 702-714. https://doi.org/10.1504/IJTM.2000.002891.

Roos G, Roos J, Edvinsson L, Dragonetti NC. 1997. Intellectual Capital - Navigating in the New
Business Landscape. New York: New York University Press.

Sveiby, KE. 2010. Methods for Measuring Intangible Assets.http://www.sveiby.com/articles/ IntangibleMethods.htm [2016 April 27].

Tan HP, Plowman D, Hancock P. 2007. Intellectual capital and financial returns of companies. Journal of Intellectual Capital 8(1): 76-95. https://doi.org/10.1108/14691930710715079.

Tayles M, Pike R, Sofian S. 2007. Intellectual capital, management accounting practices and corporate performance: perceptions of managers. Accounting, Auditing, and Accountability Journal 20(4): 522-548. https:// doi.org/10.1108/09513570710762575.

Yu KY, Ng HT, Wong WK, Samuel CKW, Chan, KH. 2010. An empirical study of the impact of Intellectual Capital performance on business performance. The 7th International Conference on Intellectual Capital, Knowlege Management \& Organisational Learning, page 1-10.

Williams S. 2000. The Association between Gender and Ethnic Diversity of Board Structure on the Intellectual Capital Performance of Publicly Listed Companies from an Emerging Economy: Evidence from South Africa. http://www.vaicon.net/download/Paper3.pdf [2016 March 16]. 